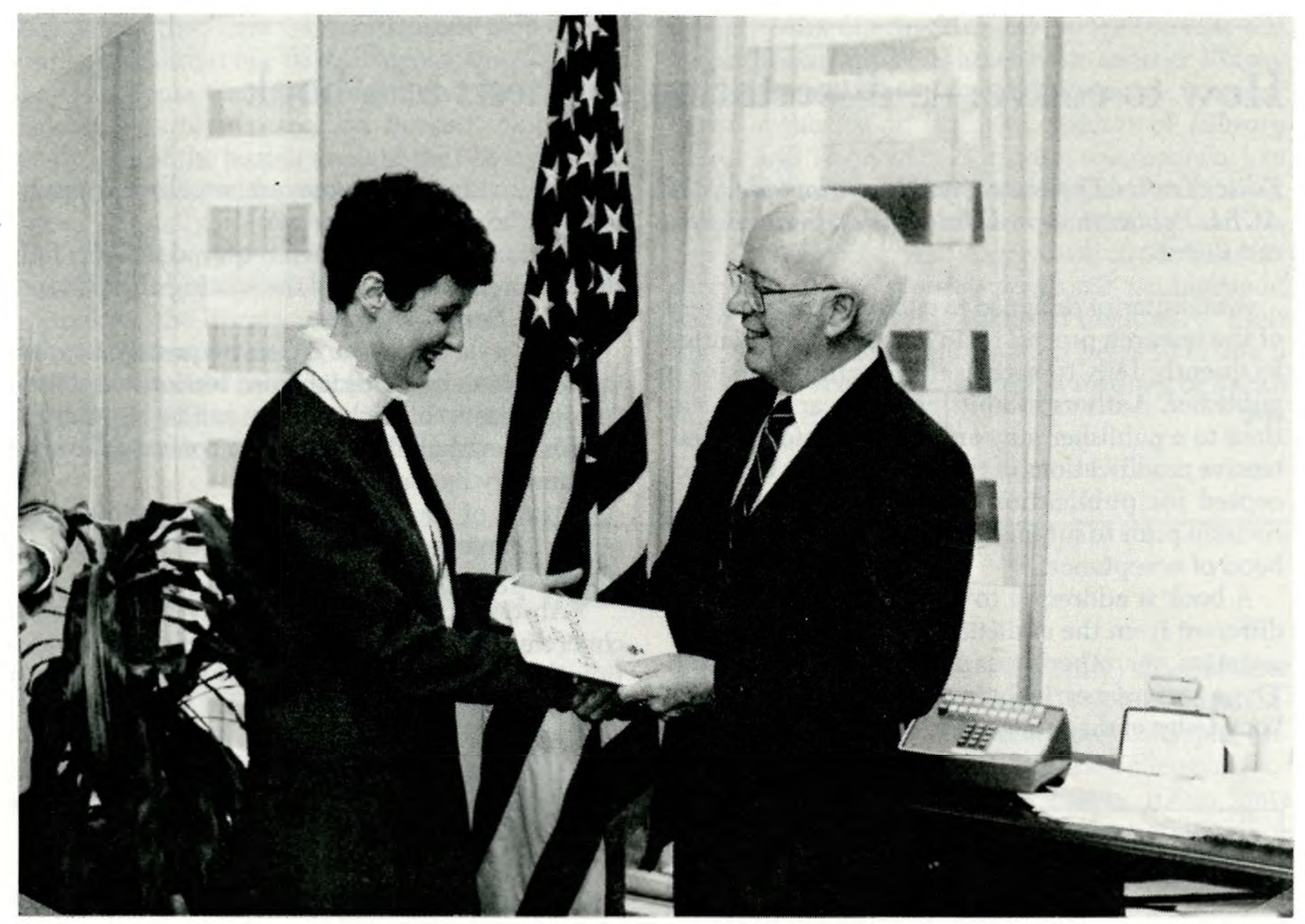

Julie Virgo receives a copy of Alliance for Excellence from Secretary of Education Terrel Bell.

\title{
Librarians respond to A Nation at Risk
}

In September 1983 the U.S. Department of Education initiated a series of small regional seminars to bring together librarians, educators, patrons, and other interested groups to identify the most effective role for libraries in a Learning Society. The primary purpose of this initiative was to respond to the landmark report of the National Commission on Excellence in Education, A Nation at Risk, which underscored the decline of educational standards in the United States, especially with regard to secondary education.

To achieve this purpose, a National Advisory Board, consisting of presidents and executive directors of major library and information science associations, was established. Joyce Ball and Julie Virgo participated on behalf of ACRL.

The Board's deliberations led to the preparation of five key position papers on specialized aspects of librarianship: public library service, school library service, academic library service, library and information science education, and library linkages and cooperative activity.

The end result of this initiative is Alliance for Excellence, a report to librarians, information scientists, educators, and the general public as to what roles various types of libraries can play towards the fuller realization of a Learning Society, the improvement of U.S. schools and colleges, and the more efficient and effective handling of information and knowledge in support of learning.

The recommendations in the report of most relevance to academic libraries are:

- "We recommend that school library media centers and public and academic libraries be open, to the fullest extent possible, to elementary and secondary school students and area residents. This policy would have the joint aims of expanding the time available for learning, while making more effective use of a community's library and information resources."

- "We recommend that libraries accept their central role in the Learning Society as valid learning centers. Further, we recommend that these centers be staffed with user-oriented professionals who not only understand community needs but also know learning resources. These 'learners' advisers would help patrons to gain the information and skills to function successfully in the Learning Society."

- "We recommend that libraries become active in adult literacy education programs at local, state, and national levels." 
- "We recommend that librarians at local, state, and national levels develop and implement plans to share the resources and services of their institutions in support of education and lifelong learning. We also recommend that at the national level, leadership should be exerted to endorse, assist, and support the states and local communities in their efforts to share resources."

- "We recommend that library and information science educators reform and refine the recruitment, preparation, and continuing education of librarians and information scientists. Further, we recommend that the entire library community hold higher education responsible for providing high-quality education to equip professionals with special competencies to work effectively in libraries and information centers in the Learning Society."

Copies of the 64-page report, Alliance for Excellence: Librarians Respond to A Nation at Risk, are available for $\$ 2.50$ from the Superintendent of Documents, U.S. Government Printing Office, Washington, DC 20402, stock no. 065-000-002-078 , and from the ERIC System in either print or microfiche format.

\section{ACRL/ISI fellowships for 1985}

The Association of College and Research Libraries solicits applications for the two fellowships made possible by the Institute for Scientific Information in Philadelphia. The first, the Samuel Lazerow Fellowship for Research in Acquisitions or Technical Services in an Academic or Research Library, honors a senior vice-president of ISI who made outstanding contributions to these fields. The fellowship of $\$ 1,000$ is to foster advances in acquisitions or technical services by providing a practicing librarian with funds for research, travel, and writing.

The second fellowship, the ACRL Doctoral Dissertation Fellowship, provides an award of $\$ 1,000$ to a doctoral student working on a dissertation in the area of academic librarianship.

Applications for both fellowships should be made to Sandy Whiteley, Associate Executive Director, ACRL/ALA, 50 E. Huron St., Chicago, IL 60611-2795, and are due by December 1, 1984 . There are no application forms for these fellowships. Candidates should submit proposals as described below. The winners of the awards will be announced at the ALA Annual Conference in Chicago in July 1985.

To be eligible for the Lazerow Award, a librarian must be working in acquisitions or technical services in an academic or research library. The Fellowship supports research in acquisitions or technical services, including the technical services aspects of library automation and library management. Research projects in collection development or the compilation of bibliographies will not be supported by this Fellowship. Application proposals should be brief (five pages or less) and include the following:

1) description of research, travel, or writing project;

2) schedule for the project;

3) an estimate of expenses.

An up-to-date curriculum vitae should accompany the proposal. Proposals for the Lazerow Award will be judged on the following:

1) potential significance of the project to acquisi- tions or technical services work;

2) originality and creativity;

3) clarity and completeness of the proposal;

4) evidence of an interest in scholarship, such as a previous publication record.

In order to be eligible for the ACRL Doctoral Dissertation Award, the applicant must meet the following qualifications:

1) be an active doctoral student in the academic librarianship area in a degree-granting institution;

2) have all coursework completed;

3) have had a dissertation proposal accepted by the institution.

The application should be brief (less than ten pages) and include the following:

1) description of the research, including significance and methodology;

2) a schedule for completion;

3) budget and budget justification for items for which support is sought (these must be items for which no other support is available);

4) the name of the dissertation advisor and committee members;

5) a cover letter from the dissertation advisor endorsing the proposal.

An up-to-date curriculum vitae should accompany the proposal. Proposals will be judged on the following criteria:

1) potential significance of the research to the field of academic librarianship;

2) validity of the methodology and proposed method of analysis;

3) originality and creativity;

4) clarity and completeness of the proposal;

5) presentation of a convincing plan for completion in a reasonable amount of time;

6) evidence of a continuing interest in scholarship, such as a previous publication record.

The winner of the 1984 Fellowship was Donald Gould, a doctoral candidate at the University of Southern California.

For further information on these fellowships, contact Sandy Whiteley, ACRL/ALA, 50 E. Huron St., Chicago, IL 60611; (312) 944-6780. 


\section{ACQUISITION PERSPECTIVES}

3. We provide each customer a listing of books not immediately available from the publisher. This monthly open order report assures you we have recently taken effective action towards earliest possible delivery of your orders. Publisher stock status and additional information are available on a continuous computer printout or on individual $3 \times 5$ slips for easy filing. We cancel only publisher-documented out-of-print or out-of-stock-indefinitely titles.

Eliminate your claiming and begin receiving your open order reports from Book House.

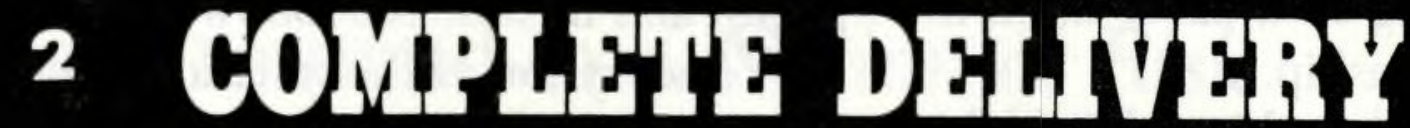

OPHI ORDAR BAPOBts

G. MIIITE TO PUBTIS:IA:

BOOK HOUSE

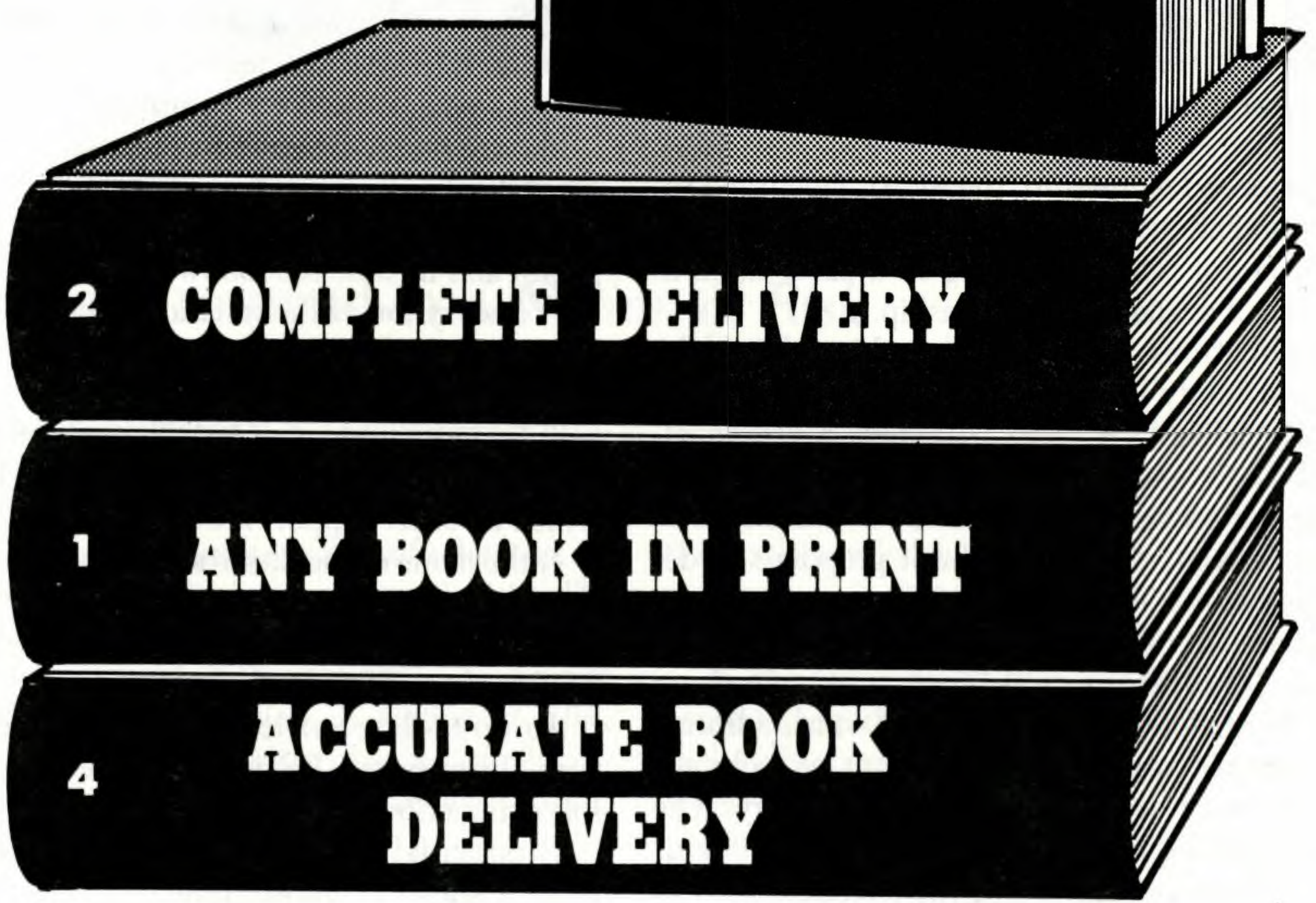

CALL TOLL-FREE TODAY

1-800-248-1146

In Canada \& Michigan

CALL COLLECT (517) 849-2117

OCLC Vendor No. 17397

SAN $169-3859$ the

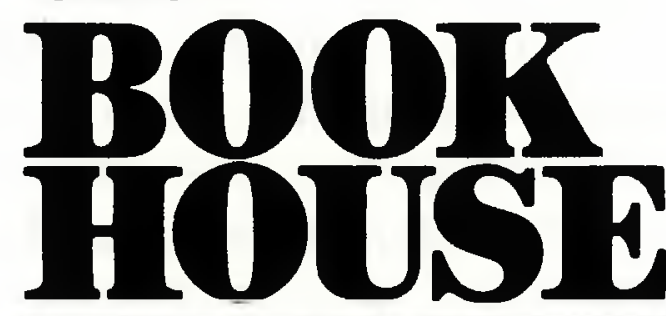

JOBBERS SERVING LIBRARIES WITH ANY BOOK IN PRINT SINCE 1962 208 WEST CHICAGO STREET JONESVILLE, MICHIGAN 49250 